\title{
Agrochemical indexes of black earth depending on fertilizer system of sugar beet and links of crop rotations
}

\author{
Ya. Tsvei, \\ Doctor of Agricultural Sciences, Professor \\ O. Torlina, \\ N. Voroniuk \\ Institute of Bioenergy Crops and Sugar Beet NAAS of Ukraine
}

The purpose. To study influence of links of crop rotations on the content of mineral nitrogen, mobile phosphorus, exchangeable potassium depending on application of fertilizers, postharvest residues of winter wheat in sugar beet sowings. Methods. Field, laboratory. Results. 3-years results of study of influence of mineral and organic fertilizers in the form of straw upon agrochemical indexes of typical weakly alkaline black earth in conditions of Forest-steppe are brought. Conclusions. At application of organomineral fertilizer system agrochemical indexes of typical weakly alkaline black earth are increased. During period of shoots of sugar beet use of straw $+\mathrm{N}_{140} \mathrm{P}_{120} \mathrm{~K}_{90}$ heightened the content of mineral nitrogen within the limits of $18,3-20,8$, mobile phosphorus $-43,0-50,7$, exchangeable potassium -125 $-135 \mathrm{mg} / \mathrm{kg}$ of soil. That did not yield to alternative with importation of dung in dose of $25 \mathrm{t} / \mathrm{hectare}+$ $\mathrm{N}_{90} \mathrm{P}_{120} \mathrm{~K}_{90}$.

Key words: typical weakly alkaline black earth, content

Problem statement. The system of crop rotation and fertilization affects the formation of the nutrient regime in the soil, the mobility and availability of nutrients, mineralization and immobilization processes in the soil (Barshtein et al. 2002,Hospodarenko2002,Nechaev et al. 2013,Poliovyi 2007, Tsvei 2014).

Under the effect of long-term regular application of manure and mineral fertilizers on chernozem soils, the nutrient content of the soils improved (Barshtein et al. 2002,Poliovyi 2007, Shymanska 1994).

For the systematic introduction of manure and mineral fertilizers, there was an increase in the content of mobile phosphorus and exchange potassium in the soil (Ivanina et al. 2013, Zarishnyak et al. 2013, Nosko 1990, Nikitshen et al. 2000, Tsvei 2014).

In modern agriculture, using by-products of grain crops as organic fertilizer improves nitrogen, phosphorus, and potassium regime of the soil, since harvest residues contribute to the recycling of nutrients in the soil- plant system (Hospodarenko2002,Nikitshen et al. 2000,Poliovyi 2007,Tsvei 2014,Shiyan 1992, Shymanska 1994).

Research by Nosko(Nosko 1990) on leached chernozemindicated that application ofP $_{34}$, both separately and with straw ( $3 \mathrm{t} / \mathrm{ha}$ ), led to the optimal phosphorus balance. Positive potassium balance was noted when $\mathrm{K}_{18}$ was added against the background of $3 \mathrm{t} / \mathrm{ha}$ straw.

The purpose of the research was to determine the effect of crop rotation links on the content of mineral nitrogen, mobile phosphorus and exchange potassium as affected by application of fertilizers and harvest residues of winter wheat straw in sugar beet sowings (Table 1).

Research methods. The research was carried out at Veselopodilska RBS (Semenivka district, Poltava region) in a long-term stationary experiment on typical deep weakly-sodicchernozem of the following characteristics: $\mathrm{pH}_{\text {sal }}$ of 7.5 , humus (by Tiurin) 4.5 to $4.8 \% ; \mathrm{P}_{2} \mathrm{O}_{5}$ and $\mathrm{K}_{2} \mathrm{O}$ (by Machigin) 30 and $100 \mathrm{mg} / \mathrm{kg}$, respectively. The alternation of crops in short rotation was as follows: grain - row crop rotation: 1) corn for silage, 2) winter wheat, 3) sugar beet, 4) barley (50\% row crops, $50 \%$ grain crops);grain - row crop rotation: 1) pea, 2) winter wheat, 3 ) winter wheat, 4$)$ sugar beet $(75 \%$ grain crops, $25 \%$ row crops); grain - fallow - row crop rotation: 1) bare fallow, 2) winter wheat, 3) sugar beet, 4) barley ( $25 \%$ bare fallow, $25 \%$ sugarbeet, $50 \%$ grain crops). Agrochemical analyseswere conductedat the period 
of germination and harvesting sugar beet. Mineral nitrogen $\left(\mathrm{NH}_{4}+\mathrm{NO}_{3}\right)$ was determinedby CINAOmethod, mobile phosphorus and exchange potassium by Machigin method. The fertilization practices used in the experiment are shown in Table 1. In the experiment, sugar beet hybrid Bulavawas grown according to generally accepted agronomical practices for the zone of sugar beet growing.

Research results indicate that the application of different fertilizationpractices in the cultivation of sugar beet has an effect on the nitrogen regime in the soil. Consequently, the level of mineral nitrogen in the soil during the period of sugar beet emergence in the treatments without fertilizers was as following: in the link with corn for silage 14.6, bare fallow 14.3 and in 2 fields of winter wheat $14.2 \mathrm{mg} / \mathrm{kg}$. Application of mineral and organic fertilizers improves the provision of soil with nitrogen due to the strengthening of nitrification and ammoniation processes in the soil (Hesse 1986, Muller \&Feyerabend 1979).

The research showed that for the application of $25 \mathrm{t} /$ ha manure $+\mathrm{N}_{90} \mathrm{P}_{120} \mathrm{~K}_{90}$, the content of mineral nitrogen of the soil was as follows: for the period of sugar beet emergence in grain - row crop rotation in the link with corn for silage it was $18.6 \mathrm{mg} / \mathrm{kg}$, in grain - row crop rotation, where sugar beets were sown on two fields following winter wheat $19.8 \mathrm{mg} / \mathrm{kg}$, in grain - fallow crop rotation in the linkof bare fallow $20.7 \mathrm{mg} / \mathrm{kg}$, which was more than by $4.0,5.6$ and $6.4 \mathrm{mg} / \mathrm{kg}$, respectively, compared to the treatment without fertilization.

According to the crop rotation, the content of mineral nitrogen in soil increased by $2.1 \mathrm{mg} / \mathrm{kg}$ due to the effect of mineralization processes and the release of $\mathrm{NH}_{4}$ and $\mathrm{NO}_{3}$ compounds in the soil. In those options of crop rotation, where a combination of manure, straw and mineral fertilizers was introduced, the content of mineral nitrogen was affected by the course of mineralization and immobilization processes. The highest content of mineral nitrogen of the soil was observed in the link of corn for silage, specifically $21.1 \mathrm{mg} / \mathrm{kg}$, which exceeded the organic \&mineral fertilization practice by $2.5 \mathrm{mg} / \mathrm{kgand}$ bare fallow by 0.6 $\mathrm{mg} / \mathrm{kg}$ only.

The combination of straw with mineral fertilizers had a special effect on the formation of the nitrogen regime of the soil during the beet sugar growing. Thus, during the period of sugar beetemergence, $5 \mathrm{t} / \mathrm{ha}$ of straw $+\mathrm{N}_{140} \mathrm{P}_{120} \mathrm{~K}_{90}$ in the link of corn for silage led to the mineral nitrogen content in the arable soil layer of $20.8 \mathrm{mg} / \mathrm{kg}$, in the link of bare fallowand two fields of winter wheat 18.3 and 18.7 $\mathrm{mg} / \mathrm{kg}$,respectively, which was higher than in the treatment without fertilization by $6.2,4.0$, and $4.5 \mathrm{mg} / \mathrm{kg}$, respectively. Under the effect of fertilization, migration of mineral nitrogen into the under-ploughed layer of soil was observed.

By the end of the sugar beet vegetation, the content of mineral nitrogen decreased both due to the assimilation by plants, and slowing down of nitrification and ammonification processes in the soil.

Thus, from the use of $25 \mathrm{t} / \mathrm{ha}$ of manure $+\mathrm{N}_{90} \mathrm{P}_{120} \mathrm{~K}_{90}$ under sugar beet, an increase in mineral nitrogen content in the under-ploughedsoil layer was observed compared to theunfertilized backgrounds, specifically, in grain - row crop rotationin the link ofcorn for silage, this indicator increased by 3.9; in the grain -fallow - row crop rotation in the link ofbare fallow by 4.9 and winter wheat by $2.4 \mathrm{mg} / \mathrm{kg}$. Such growth was due to the migration of $\mathrm{NO}_{3}$ compounds to the lower layers of the soil.

By the end of sugar beet growing season, the content of mineral nitrogen in the soil decreased both due to the use of itby plants, and slowing down of nitrification and ammoniation processes in the soil.

Practice of the organic \& mineral fertilization improves phosphate regime of chernozem soils (Nosko 1990, Nikitshen et al. 2000, Kochl 1982). Thus, for the application of $25 \mathrm{t} /$ ha of manure $+\mathrm{N}_{90} \mathrm{P}_{120} \mathrm{~K}_{90}$, the content of mobile phosphorus in the soil amounted to $52.2 \mathrm{mg} / \mathrm{kg}$ during the period of sugar beet emergence, in the link of corn for silage, in 2 fields of winter wheat $45.7 \mathrm{mg} / \mathrm{kg}$, and in the link of bare fallow $51.3 \mathrm{mg} / \mathrm{kg}$, which was greater than in the unfertilized treatment by $22.9,15.6$, and $18.3 \mathrm{mg} / \mathrm{kg}$, respectively. Consequently, organic \& mineral fertilization ensure a substantial increase in the content of mobile phosphorus in the soil.

In the treatment where 25 tha of manure + straw $+\mathrm{N}_{90} \mathrm{P}_{120} \mathrm{~K}_{90}$ was used, the content of mobile phosphorus of the soil in the link of corn for silage was $51.2 \mathrm{mg} / \mathrm{kg}$, in two fields of winter wheat 49.8 $\mathrm{mg} / \mathrm{kg}$ and in the link of bare fallow $50.5 \mathrm{mg} / \mathrm{kg}$. 
Under introduction of $5 \mathrm{t} /$ ha straw $+\mathrm{N}_{140} \mathrm{P}_{120} \mathrm{~K}_{90}$, the mobile phosphorus content in the ploughed soil layer was as follows: in the link of corn for silage 50.7, in the link of bare fallow 45.0, and winter wheat $43.0 \mathrm{mg} / \mathrm{kg}$, which was almost not inferior to the above described fertilization practices.

Under the effect of fertilizers, an increase in the content of mobile phosphorus in the underploughedsoil layer was observed. To illustrate, in the soil layer of $30-60 \mathrm{~cm}$, mobile phosphorus content against the background of $25 \mathrm{t} / \mathrm{h}$ a of manure + straw $+\mathrm{N}_{90} \mathrm{P}_{120} \mathrm{~K}_{90}$ in the link of corn for silage increased to 37.0 , in the link ofbare fallow to 38.0 and winter wheat to $39.3 \mathrm{mg} / \mathrm{kg}$, which exceeded the unfertilized background by $14.0,15.0$, and $11.3 \mathrm{mg} / \mathrm{kg}$, respectively. At the end of sugar beet growing season, mobile phosphorus content of the soil decreased both due to the assimilation by plantsand the transition of phosphates into slow-moving compounds.

Typical weakly sodicchernozemshave a high level of supply with exchange potassium. At the same time, both in mineral and in the organic \&mineral fertilization systems there is an increase in $\mathrm{P}$ content (Hospodarenko 2002, Ivanina et al. 2013,Zarishnyak et al. 2013,Poliovyi 2007). In the treatment where 25 $\mathrm{t} /$ ha of manure $+\mathrm{N}_{90} \mathrm{P}_{120} \mathrm{~K}_{90}$ wasapplied at the beginning ofsugar beet vegetation in the link of corn for silage, $\mathrm{P}$ content in the ploughed soil layer was 131.0, whereas in 2 fields of winter wheatit was 131.0 and in the link of bare fallow $129.0 \mathrm{mg} / \mathrm{kg}$, which was higher than in the unfertilized treatments by 40.0, 37.0, and $37.0 \mathrm{mg} / \mathrm{kg}$, respectively. When applying $25 \mathrm{t} / \mathrm{ha}$ of manure + straw $+\mathrm{N}_{90} \mathrm{P}_{120} \mathrm{~K}_{90}, \mathrm{P}$ content in thesoil was $135.0,154.0$ and $149.0 \mathrm{mg} / \mathrm{kg}$, respectively, indicating a slight increase due to application of $25 \mathrm{t} / \mathrm{ha}$ of manure $+\mathrm{N}_{90} \mathrm{P}_{120} \mathrm{~K}_{90}$.

In the treatment, where straw and mineral fertilizers were combined, the content of exchangeable potassium in the arable layer of soil was at the same level with the option of $25 \mathrm{t} / \mathrm{ha}$ of manure $+\mathrm{N}_{90} \mathrm{P}_{120} \mathrm{~K}_{90}$. The highest content of $\mathrm{P}$ of the soil was observed in the link of corn for silage, specifically $135.0 \mathrm{mg} / \mathrm{kg}$, while in the link of bare fallow it was $130.0 \mathrm{mg} / \mathrm{kg}$.

Consequently, the combination of straw with mineral fertilizers contributes to the optimal content of exchangeable potassium in the soil.

In the under-ploughedsoil layer, there was an increase in the content of exchangeable potassium compared to unfertilized treatments. For the above mentioned fertilization practice, the content of exchangeable potassium in the soilin the link of corn for silage ranged from 89.0 to 102.0, in the link of bare fallow from 96.0 to 113.0 , in 2 fields of winterwheat from 85.0 to $102.0 \mathrm{mg} / \mathrm{kg}$, whereas without fertilizers the range was 63.0 to $72.0 \mathrm{mg} / \mathrm{kg}$.

By the end of the sugar beet vegetation, the content of exchangeable potassium decreased both due to the use by plants and transition to unexchange fixed state. Thus, against the background of $25 \mathrm{t} / \mathrm{ha}$ of manure $+\mathrm{N}_{90} \mathrm{P}_{120} \mathrm{~K}_{90}, \mathrm{P}$ contentof the soil in the link of corn for silage was 110.0 , in the link of bare fallow 114.0 and in the link of winter wheat $108.0 \mathrm{mg} / \mathrm{kg}$, which was less than during period of beet sugar emergence by $21.0,15.0$, and $23.0 \mathrm{mg} / \mathrm{kg}$, respectively; in the treatment with straw $+\mathrm{N}_{140} \mathrm{P}_{120} \mathrm{~K}_{90}$ it was $110,0,109.0$, and $116.0 \mathrm{mg} / \mathrm{kg}$, respectively.

Consequently, the nutritional regime of typical weakly-sodicchernozemis more affected by fertilization practice for sugar beet, than by crop rotation links. Ploughing-in straw with manure and fertilizers helps to optimize the nutrient regime of the soil.

Table 1. Effect of fertilization practice forsugar beet and crop rotation links on agro-chemical indices $(\mathrm{mg} / \mathrm{kg}$ ) of typical weakly sodicchernozem in shortcrop rotations (VPRBS), average from 2012 to 2014.

\begin{tabular}{|c|c|c|c|c|c|c|c|c|}
\hline \multirow[b]{2}{*}{ No } & \multirow[b]{2}{*}{ Fertilizationpractice } & \multirow{2}{*}{$\begin{array}{l}\text { Soil } \\
\text { layer } \\
(\mathrm{cm})\end{array}$} & \multicolumn{2}{|c|}{$\mathrm{NH}_{4}+\mathrm{NO}_{3}$} & \multicolumn{2}{|l|}{$\mathrm{P}_{2} \mathrm{O}_{5}$} & \multicolumn{2}{|l|}{$\mathrm{K}_{2} \mathrm{O}$} \\
\hline & & & $1^{*}$ & $11^{* \star}$ & $1^{*}$ & $11^{* *}$ & $1^{*}$ & $11^{\text {** }}$ \\
\hline \multicolumn{9}{|c|}{ Grain - rowcroprotation (corn for silage) } \\
\hline \multirow[t]{2}{*}{27} & \multirow[t]{2}{*}{ No fertilizers } & $0-30$ & 14.6 & 13.1 & 29.3 & 26.3 & 91.0 & 67.0 \\
\hline & & $30-60$ & 12.0 & 10.7 & 23.0 & 21.0 & 63.0 & 49.0 \\
\hline
\end{tabular}




\begin{tabular}{|c|c|c|c|c|c|c|c|c|}
\hline \multirow[t]{2}{*}{28} & \multirow[t]{2}{*}{$25 \mathrm{t} /$ ha manure $+\mathrm{N}_{90} \mathrm{P}_{120} \mathrm{~K}_{90}$} & $0-30$ & 18.6 & 17.3 & 52.2 & 41.8 & 131.0 & 110.0 \\
\hline & & $30-60$ & 15.7 & 14.6 & 35.0 & 31.3 & 102.0 & 82.0 \\
\hline \multirow[t]{2}{*}{29} & \multirow[t]{2}{*}{$25 \mathrm{t} /$ ha manure + straw $+\mathrm{N}_{90} \mathrm{P}_{120} \mathrm{~K}_{90}$} & $0-30$ & 21.1 & 18.6 & 51.2 & 42.3 & 135.0 & 125.0 \\
\hline & & $30-60$ & 17.6 & 15.6 & 37.0 & 34.0 & 92.0 & 80.0 \\
\hline \multirow[t]{2}{*}{30} & \multirow[t]{2}{*}{ Straw $+\mathrm{N}_{140} \mathrm{P}_{120} \mathrm{~K}_{90}$} & $0-30$ & 20.8 & 19.3 & 50.7 & 43.5 & 135.0 & 110.0 \\
\hline & & $30-60$ & 12.8 & 14.2 & 39.7 & 36.0 & 89.0 & 69.0 \\
\hline \multicolumn{9}{|c|}{ Grain - fallow - rowcroprotation(bare fallow) } \\
\hline \multirow[t]{2}{*}{45} & \multirow[t]{2}{*}{ No fertilizers } & $0-30$ & 14.3 & 12.7 & 32.2 & 28.3 & 92.0 & 74.0 \\
\hline & & $30-60$ & 11.5 & 9.3 & 23.0 & 20.3 & 72.0 & 52.0 \\
\hline \multirow[t]{2}{*}{46} & \multirow[t]{2}{*}{$25 \mathrm{t} /$ ha manure $+\mathrm{N}_{90} \mathrm{P}_{120} \mathrm{~K}_{90}$} & $0-30$ & 20.7 & 18.8 & 51.3 & 44.0 & 129.0 & 114.0 \\
\hline & & $30-60$ & 16.3 & 14.2 & 35.3 & 28.7 & 96.0 & 83.0 \\
\hline \multirow[t]{2}{*}{47} & \multirow[t]{2}{*}{$25 \mathrm{t} /$ ha manure + straw $+\mathrm{N}_{90} \mathrm{P}_{120} \mathrm{~K}_{90}$} & $0-30$ & 21.3 & 19.2 & 50.5 & 45.8 & 149.0 & 114.0 \\
\hline & & $30-60$ & 16.7 & 14.5 & 38.0 & 30.3 & 113.0 & 79.3 \\
\hline \multirow[t]{2}{*}{48} & \multirow[t]{2}{*}{ Straw $+\mathrm{N}_{140} \mathrm{P}_{120} \mathrm{~K}_{90}$} & $0-30$ & 18.3 & 17.4 & 45.0 & 40.0 & 130.0 & 109.0 \\
\hline & & $30-60$ & 13.7 & 13.5 & 30.3 & 28.3 & 102.0 & 68.0 \\
\hline \multicolumn{9}{|c|}{ Grain - rowcroprotation (two fields of winter wheat) } \\
\hline \multirow[t]{2}{*}{63} & \multirow[t]{2}{*}{ No fertilizers } & $0-30$ & 14.2 & 12.7 & 34.2 & 30.2 & 94.0 & 85.0 \\
\hline & & $30-60$ & 12.5 & 10.3 & 28.0 & 25.0 & 71.0 & 56.0 \\
\hline \multirow[t]{2}{*}{64} & \multirow[t]{2}{*}{$25 \mathrm{t} /$ ha manure $+\mathrm{N}_{90} \mathrm{P}_{120} \mathrm{~K}_{90}$} & $0-30$ & 19.8 & 17.9 & 45.7 & 41.7 & 131.0 & 108.0 \\
\hline & & $30-60$ & 14.4 & 12.7 & 35.7 & 31.3 & 89.0 & 79.0 \\
\hline \multirow[t]{2}{*}{65} & \multirow[t]{2}{*}{$25 \mathrm{t} /$ ha manure + straw $+\mathrm{N}_{90} \mathrm{P}_{120} \mathrm{~K}_{90}$} & $0-30$ & 20.6 & 18.2 & 49.8 & 46.2 & 154.0 & 124.0 \\
\hline & & $30-60$ & 14.4 & 12.9 & 39.3 & 33.6 & 102.0 & 73.0 \\
\hline \multirow[t]{2}{*}{66} & \multirow[t]{2}{*}{ Straw $+\mathrm{N}_{140} \mathrm{P}_{120} \mathrm{~K}_{90}$} & $0-30$ & 18.7 & 17.5 & 43.0 & 40.2 & 125.0 & 116.0 \\
\hline & & $30-60$ & 13.8 & 12.6 & 34.7 & 31.0 & 85.0 & 80.0 \\
\hline
\end{tabular}

*1 emergence; **11end of vegetation period.

\section{Conclusions}

The study has proved that combination of $25 \mathrm{t} /$ ha of manure + straw $+\mathrm{N}_{90} \mathrm{P}_{120} \mathrm{~K}_{90}$ Oincreasesthe content of mineral nitrogen of the soil during the period of sugar beet emergencefrom 20.6 to $21.3 \mathrm{mg} / \mathrm{kg}$, whereas the application of $25 \mathrm{t} /$ ha of manure $+\mathrm{N}_{90} \mathrm{P}_{120} \mathrm{~K}_{90}$ increase mineral nitrogen content of the soil by $17.3-18.8 \mathrm{mg} / \mathrm{kg}$.

Introduction of $25 \mathrm{t} /$ ha of manure + straw $+\mathrm{N}_{90} \mathrm{P}_{120} \mathrm{~K}_{90}$ contributed to the increase in mobile phosphorus content of soil by $26.3-30.2 \mathrm{mg} / \mathrm{kg}$ as compared to unfertilized background. At the end of the sugar beet vegetation, the content of mobile phosphorus decreased, due to the uptake by plants.

Ploughing-in straw contributed to the improvement of the potassium regime of typicalchernozem. Against the background of $25 \mathrm{t} /$ ha of manure + straw $+\mathrm{N}_{90} \mathrm{P}_{120} \mathrm{~K}_{90}$, the content of exchange potassium of the soil increased at the period of sugar beet emergence by $44.0-60.0 \mathrm{mg} / \mathrm{kg}$ as compared to unfertilized backgroundand ranged from 135.0 to $154.0 \mathrm{mg} / \mathrm{kg}$. At the end of vegetation, the content of exchange potassium decreased by $10-23 \mathrm{mg} \mathrm{kg}$.

\section{Bibliography}

1. Barshtein, L.A.,Shkarednyi, I. S.,Barshtein, I.S.\&Yakimenko, V.M. (2002). Crop rotations, soil cultivation and fertilization in beet-growing zones.Naukovipratsilnstytututsukrovykhburiakiv [Scientific Papers of the Institute of Sugar Beet].[in Ukrainian]

2. Hospodarenko, H. M. (2002). Fundamentals of integrated application of fertilizers.Kyiv: Nehlava. [in Ukrainian]

3. Ivanina, V.V.,Shymanska, N.K \&Mazur, G.M. (2013).Biologization measures in the formation of the phosphate regime of typical chernozem.Visnykahrarnoinauky[Bulletin of Agrarian Science], 12, 21. [in Ukrainian] 
4. Zarishnyak, A.C.,Ivanina, V.V.,\&Kalibabchuk, T.V. (2013). Optimization of sugar beet nutrition in crop rotation links.Sakharnayasvekla [Sugar beet], 4, 13. [in Russian]

5. Nechaev, L.A.,Torubanov,N. P. \&Chernenky, V.A. (2002). The system of soil fertility reclamation.Zemledelie [Agriculture], 5, 13. [in Russian]

6. Nosko, B.S. (1990). Phosphate regime of soil and fertilizer efficiency.Kyiv: Urozhay. [in Ukrainian]

7. Nikitshen, V. I.,Dmytrakova, P. K. \&Lichko,V. I.(2000).The role of soil and fertilizer in providing potash nutrition to crops.Agrohimiya [Agrochemistry], 12, 30. [in Russian]

8. Poliovyi, V. M. (2007).Optimization of fertilizer systems in modern agriculture.Rivne: Volynskioberehy. [in Ukrainian]

9. Tsvei,Ya.P. (2014).Soil fertility and crop rotation productivity.Kyiv: COMPRINT. [in Ukrainian]

10. Shiyan, P.M. (1992). Optimization of nitrogen supply of sugar beet and its diagnostics .Optymizatsiaazotnohozhylennia pry intesvykhtekhnologiiakh[Optimization of nitrogen supply with intensive technologies]. Kyiv: Urozhay. [in Ukrainian]

11. Shymanska, N.K. (1994). Effect of fertilizers on soil fertility, yield and quality of crops of grain and beet crop rotation.Rezervyproduktyvnostisilskohospodarskykhkulturburiakovoisivozminy[Reserves of productivity of agricultural crops of beet crop rotation]. Kyiv. [in Ukrainian]

12. Hesse, F. (1986).QualitätsrübeerzeugeungmitorganischerDüngung.Zuckerrübe, 35(6), 272-274.

13. Kochl, A. (1982).Phosphor schmeckt der Rube gut. Agrozucker, 1, 313-331.

14. Muller, A.V. \&Feyerabend, I. C. (1979).Versuche auf Bodenmitabgestuftem N-VorratzurErmittlung des OptimalenStickstoffangebotesfür die Zuckerrübe. Zuckeerindustrie, (29)6, 485-488. 